\title{
Research on O2O's Connotation of Promoting Catering Enterprises' Value Growth
}

\author{
Zhao Jingjing \\ School of Economic Management \\ Changchun University of Technology \\ Changchun, China \\ zhaojj127@163.com
}

\author{
Liu Lianpeng \\ School of Economic Management \\ Changchun University of Technology \\ Changchun, China
}

\begin{abstract}
The purpose of this article is to explore the trend of 020 promoting the value growth of catering enterprises. The basic research object of the article is catering enterprises on the third party 020 platform. Based on the data of the 020 platform, the paper explores that $\mathbf{O 2 O}$ platform has changed the operation status of small and micro catering enterprises and has shown a new trend. According to the directive law of the consumer price curve PCC, the representation index of value growth and the corresponding value space are presented and discussed to show the new trend.
\end{abstract} mode

Keywords-O2O; value growth; catering enterprises; $\mathrm{O} 2 \mathrm{O}$

\section{INTRODUCTION}

China has witnessed explosive growth in the practice field of $\mathrm{O} 2 \mathrm{O}$ business mode. The third party $\mathrm{O} 2 \mathrm{O}$ platform is becoming more and more perfect, and the enterprise practice based on the $\mathrm{O} 2 \mathrm{O}$ model emerges in endlessly. $\mathrm{O} 2 \mathrm{O}$ has become the mainstream e-commerce business model in China. In recent years, $\mathrm{O} 2 \mathrm{O}$ books and articles are constantly emerging. $\mathrm{O} 2 \mathrm{O}$ research has become a new research hotspot in the field of electronic commerce. The related research of $\mathrm{O} 2 \mathrm{O}$ in local life service industry is mostly about the evaluation system of $\mathrm{O} 2 \mathrm{O}$ model[1] and model itself[2]. It mainly focuses on the inherent unique problems of $\mathrm{O} 2 \mathrm{O}$ business model, such as business goodwill management, product (service) promotion mode, inventory management method to meet line and line integration[3], and deep case analysis of typical enterprises[4].

Compared with foreign research, domestic scholars have highlighted the practical significance of the research, most of which combine the research of $\mathrm{O} 2 \mathrm{O}$ with the transformation and upgrading of service industry[5]. The focus of research mainly focuses on key success factors, marketing strategies of products or services, the supporting environment of $\mathrm{O} 2 \mathrm{O}$ business model[6], and user behavior under the $\mathrm{O} 2 \mathrm{O}$ environment[7].

In the micro level research of enterprises, the focus of researchers is focused on the $\mathrm{O} 2 \mathrm{O}$ mode rather than the value function of enterprises. The growth of enterprise value lacks systematic and in-depth research. Therefore, this article explores the motivation and connotation of the value growth

Fund Project: the social science project of the Jilin Provincial Education Department in 2017 (project number: JJKH20170585SK) and Jilin Province social science research project in 2016 (2016B53) of catering enterprises.

\section{THE CONCEPT OF O2O}

O2O, Online To Offline ("online offline" or "offline to line") refers to the combination of business opportunities under the line and the Internet, making the Internet a platform for offline transactions, or a management platform for offline transactions. $\mathrm{O} 2 \mathrm{O}$ is the way to turn offline business activities into online transactions and management methods combined with the Internet. Local life service $\mathrm{O} 2 \mathrm{O}$ refers to the local life service enterprises through the Internet online channels, to provide consumers with online reservation, order, payment, after service, such as one or more, that is called local life service $\mathrm{O} 2 \mathrm{O}$.

With the powerful capability of mobile Internet, $\mathrm{O} 2 \mathrm{O}$ provides online consumers with information about products and services of offline merchants. Consumers order and pay online, and get products or service experience online by using electronic credentials. Consumers evaluate and feedback services and products online. Businesses obtain and excavate consumer data and information, accurately predict potential customers, and provide preferential information for related products and services online, forming a closed loop structure of the $\mathrm{O} 2 \mathrm{O}$ value chain.

\section{The COMmercial VAlue of O2O to The EnTERPRISE}

O2O optimizes the internal management process of enterprises, instead of traditional manual means, reduces manual use, improves operational efficiency, and truly optimizes internal processes.

O2O uses Internet means to collect data and establish data analysis mode to provide support for business decision making. It is true to provide management support.

The use of interconnected means of marketing can break down geographical restrictions and expand coverage, while enriching marketing methods and enhancing attractiveness to consumers.

Use Internet tools to optimize service processes, improve service quality, enhance consumer experience and attract more customers. The sales service is profitable. It can also offer group buying to consumers, and make value-added services such as paid appointments to make profits. 


\section{The Status And TRend of O2O In CATERING ENTERPRISES}

Since 2010, the growth rate of local life service market in China has been over $10 \%$, and will continue to maintain rapid growth in the next few years. According to ARI's monitoring data[8], the scale of China's Internet economy and the $\mathrm{O} 2 \mathrm{O}$ market scale have maintained more than 30\% growth in recent years, reaching 870 billion 620 million Yuan and 235 billion 80 million Yuan respectively in 2014. In 2017, it reached 72805 billion. In recent years, the growth rate is more than $30 \%$, according to the forecast of Erie[1], the penetration rate in 2014 is close to $4.4 \%$. Experienced explosive growth of 2010 and 2011, and rapid growth in recent years, the popularity of local life service $\mathrm{O} 2 \mathrm{O}$ has reached $40 \%$, and its popularity is high.

According to China Electronic Commerce Research Center issued by the China electronic commerce market data monitoring report of 2015 (upper)[9], in the first half of 2015, China's e-commerce trading volume was 7 trillion and 630 billion Yuan, up 30.4\% over the same period. It's more than Eric's statistics. 2016 the scale of China's life service ecommerce market is 970 billion Yuan. In 2016, China's online catering takeaway market exploded, with a transaction scale of about 152 billion 400 million Yuan, an increase of 232\% compared to 45 billion 900 million in 2015.

At present, the two major O2O platforms, "meituan" and "ele", monopolize the $\mathrm{O} 2 \mathrm{O}$ services of the vast majority of catering enterprises in China. $\mathrm{O} 2 \mathrm{O}$ relies on the large number of online orders, and is deeply favored by small and micro catering enterprises. The promotion strategy of $\mathrm{O} 2 \mathrm{O}$ platform: low application service threshold, low service cost, simple and easy to use method, careful customer service, automatic distribution of logistics distribution and so on, so that the promotion speed and coverage area of $\mathrm{O} 2 \mathrm{O}$ in catering enterprises are increasing exponentially. Even some small catering enterprises in order to save business costs, only through the $\mathrm{O} 2 \mathrm{O}$ platform to carry out catering services, do not set up a physical store. Therefore, there is no local region, the vast majority of small and medium sized and micro catering enterprises in the establishment of the store, in the United States and the hungry platform on the platform for $\mathrm{O} 2 \mathrm{O}$ service.

Using the web crawler program, we obtain the data of the catering enterprises in Beijing, Shanghai, and Guangzhou during the 2018 Spring Festival. And the data of the catering enterprises in 8 three line cities of Jilin Province were obtained. Here only lists the data of Baishan city, Yanbian city, Tonghua city. In contrast, relevant data of the capital cities of three northeast provinces were also listed.

Table I gives the data of first-tier cities Beijing, Shanghai and Guangzhou. These data includes the number of catering enterprises registered in the meituan website; the average score of all catering enterprises in certain city; the average price of all catering enterprises in certain city; the average number of catering enterprises' comments existed in meituan website. Table II gives the data of the capital cities in three northeast provinces. Table III gives the data of third-tier cities Baishan, Yanbian, and Tonghua. The data structure of the other tables is the same as Table I. All collection time points of three tables are the same. They are before and after the Spring Festival.

TABLE I. COMPARISON OF BEIJING SHANGHAI GUANGZHOU DAT A BEFORE AND AFTER THE SPRING FESTIVAL

\begin{tabular}{|l|c|c|c|}
\hline \multicolumn{1}{|c|}{ Item } & Beijing & Shanghai & Guangzhou \\
\hline $\begin{array}{l}\text { Number of } \\
\text { Catering } \\
\text { Enterprises before } \\
\text { Festival }\end{array}$ & 416 & 447 & 488 \\
\hline $\begin{array}{l}\text { Number of } \\
\text { Catering } \\
\text { Enterprises after } \\
\text { Festival }\end{array}$ & 433 & 485 & 446 \\
\hline $\begin{array}{l}\text { Average Score } \\
\text { before Festival }\end{array}$ & 4.33 & 4.34 & 4.27 \\
\hline $\begin{array}{l}\text { Average Score } \\
\text { after Festival }\end{array}$ & 4.23 & 4.22 & 4.20 \\
\hline $\begin{array}{l}\text { Average Price } \\
\text { before Festival }\end{array}$ & 82.5 & 76.57 & 56.83 \\
\hline $\begin{array}{l}\text { Average Price } \\
\text { after Festival }\end{array}$ & 81.98 & 76.57 & 4518.56 \\
\hline $\begin{array}{l}\text { Comments' } \\
\text { number before } \\
\text { Festival }\end{array}$ & 4574.67 & 3583.63 & 4791.83 \\
\hline $\begin{array}{l}\text { Comments after } \\
\text { Festival }\end{array}$ & 4563.46 & 3417.26 & \\
\hline
\end{tabular}

According to statistics, the number of $\mathrm{O} 2 \mathrm{O}$ catering enterprises registered in the third-tier cities is sometimes greater than the number of $\mathrm{O} 2 \mathrm{O}$ catering enterprises registered in the second-tier cities or first-tier cities. But there is a great difference in the number of customer orders, and the consumption power of first-tier line cities is stronger. The difference between the purchasing power of the third tier cities and the first-tier cities is solidified.

TABLE II. COMPARISON OF CAPIT AL CITIES’ DAT A IN NORTHEAST PROVINCES BEFORE AND AFTER THE SPRING FESTIVAL

\begin{tabular}{|l|c|c|c|}
\hline \multicolumn{1}{|c|}{ Item } & Changchun & Shenyang & Harerbin \\
\hline $\begin{array}{l}\text { Number of } \\
\text { Catering } \\
\text { Enterprises before } \\
\text { Festival }\end{array}$ & 411 & 392 & 401 \\
\hline $\begin{array}{l}\text { Number of } \\
\text { Catering } \\
\text { Enterprises after } \\
\text { Festival }\end{array}$ & 401 & 385 & 403 \\
\hline $\begin{array}{l}\text { Average Score } \\
\text { before Festival }\end{array}$ & 4.51 & 5.55 & 4.52 \\
\hline $\begin{array}{l}\text { Average Score } \\
\text { after Festival }\end{array}$ & 4.44 & 4.47 & 4.45 \\
\hline $\begin{array}{l}\text { Average Price } \\
\text { before Festival }\end{array}$ & 57.59 & 56.42 & 57.66 \\
\hline $\begin{array}{l}\text { Average Price } \\
\text { after Festival }\end{array}$ & 57.33 & 56.62 & 5905.77 \\
\hline $\begin{array}{l}\text { Comments' } \\
\text { number before } \\
\text { Festival }\end{array}$ & 3990 & 5262.1 & 5878.62 \\
\hline $\begin{array}{l}\text { Comments after } \\
\text { Festival }\end{array}$ & 4042.53 & 5336.47 & \\
\hline
\end{tabular}


TABLE III. COMPARISON OF THIRD-TIER CITIES' DAT A BEFORE AND AFTER THE SPRING FESTIVAL

\begin{tabular}{|l|c|c|c|}
\hline \multicolumn{1}{|c|}{ Item } & Baishan & Yanbian & Tonghua \\
\hline $\begin{array}{l}\text { Number of } \\
\text { Catering } \\
\text { Enterprises before } \\
\text { Festival }\end{array}$ & 357 & 681 & 602 \\
\hline $\begin{array}{l}\text { Number of } \\
\text { Catering } \\
\text { Enterprises after } \\
\text { Festival }\end{array}$ & 356 & 694 & 611 \\
\hline $\begin{array}{l}\text { Average Score } \\
\text { before Festival }\end{array}$ & 3.38 & 3.98 & 4.46 \\
\hline $\begin{array}{l}\text { Average Score } \\
\text { after Festival }\end{array}$ & 3.33 & 3.93 & 25.13 \\
\hline $\begin{array}{l}\text { Average Price } \\
\text { before Festival }\end{array}$ & 24.24 & 34.23 & 24.88 \\
\hline $\begin{array}{l}\text { Average Price } \\
\text { after Festival }\end{array}$ & 24.46 & 34.22 & 454.92 \\
\hline $\begin{array}{l}\text { Comments’ } \\
\text { number before } \\
\text { Festival }\end{array}$ & 262.67 & 224.36 & 421.98 \\
\hline $\begin{array}{l}\text { Comments after } \\
\text { Festival }\end{array}$ & 261.79 & 227.25 & \\
\hline
\end{tabular}

V. The Connotation of Value Growth

Growth and value-added is a hot issue for $\mathrm{O} 2 \mathrm{O}$ to promote the development of catering enterprises. The active quantity of catering enterprises in each area can only indicate the current state, but can not measure and mark the development and value growth of enterprises. The original foundation and scale of enterprises and enterprises are different. It is unreasonable to evaluate enterprises only according to the level of a state stage.

$\mathrm{O} 2 \mathrm{O}$ platform data is recorded at a certain time, in a geographic location of the enterprise, customers through the use of $\mathrm{O} 2 \mathrm{O}$ platform or $\mathrm{O} 2 \mathrm{O}$ program to establish the consumption order of food and beverage orders. It is a dynamic description of the business relationship established between the customers, the merchants and the $\mathrm{O} 2 \mathrm{O}$ platform (O2O service provider) within the given time and space constraints. The three are closely linked. It is our concern that how to calculate the value growth data of catering enterprises in dynamic data.

In a certain period of time, the $\mathrm{O} 2 \mathrm{O}$ business of an enterprise actually has many kinds of measurement. When the actual $\mathrm{O} 2 \mathrm{O}$ business occurs, the "order quantity", "per capita consumption amount" and "store score" are the most direct data indicators. "Online clicks" and "online collections" are indicators of potential business. Potential business is an uncertain factor, and it can not calibrate its value growth space. The number of orders increased with time. The number of orders growth in unit time fluctuated with the objective factors such as season and discount, and the increase of the order value was not obvious. Only "per capita consumption" and "shop rating" are the direct correlation indicators of the value growth space. According to the directive law of the consumer price curve PCC, table IV gives the distribution map of the value growth space.

In Table IV, the bottom color is white, indicating that there is no improvement in value, yellow indicates value increase, and blue for value reduction. Table IV is a qualitative space for value growth.

\section{TABLE IV. VALUE GROWTH SPACE}

\begin{tabular}{|l|c|c|c|}
\hline $\begin{array}{l}\text { Value } \\
\text { Evaluation } \\
\text { Item }\end{array}$ & $\begin{array}{c}\text { Lower Per Capita } \\
\text { Consumption }\end{array}$ & $\begin{array}{c}\text { Higher Per } \\
\text { Capita } \\
\text { Consumption }\end{array}$ & $\begin{array}{c}\text { Equal Per Capita } \\
\text { Consumption }\end{array}$ \\
\hline $\begin{array}{l}\text { Lower } \\
\text { Enterprise } \\
\text { Score }\end{array}$ & Value reduction & No Ascension & Value reduction \\
\hline $\begin{array}{l}\text { Higher } \\
\text { Enterprise } \\
\text { Score }\end{array}$ & No Ascension & Value Rise & Value Rise \\
\hline $\begin{array}{l}\text { Equal } \\
\text { Enterprise } \\
\text { Score }\end{array}$ & Value reduction & Value Rise & No Ascension \\
\hline
\end{tabular}

\section{CONCLUSION}

The development and application of $\mathrm{O} 2 \mathrm{O}$ bring the prosperity of small catering enterprises. $\mathrm{O} 2 \mathrm{O}$ has changed the business model of the catering business. With the accumulation of data in the $\mathrm{O} 2 \mathrm{O}$ platform, whole analysis provides reliable data sources for the growth of catering enterprises. By crawling the data before and after the Spring Festival, we found that the small and micro catering enterprises can effectively control the cost with the help of $\mathrm{O} 2 \mathrm{O}$, and the regional advantage has been weakened partly in front of the advantages of the $\mathrm{O} 2 \mathrm{O}$ platform. According to the indication law of consumer price curve, the trend of value growth is revealed through the change of data volume per capita consumption and store rating. In the future, the method of machine learning is further used to calculate the degree of value growth on the basis of crawling data, and the influence factors of value growth are estimated by using association analysis.

\section{REFERENCES}

[1] H. Yunyun, O2O business model evaluation based on value chain[D], Nanjing University of Posts and Telecommunications.2016. (In Chinese)

[2] L. Jinfeng, Local life service $\mathrm{O} 2 \mathrm{O}$ business model evaluation index system, Observation review. 2017: pp.16-17.DOI:10.14011 (In Chinese)

[3] H.Westergren \& J.Holmstrom, “Exploring Preconditions for Open Innovation:Value Networks in Industrial Firms," Information and Organization,Vol.22, No.4, 2012, pp.209-226.

[4] G. Yan, Study on Influencing Factors of O2O mode activity in business circle -- Based on an example of O2O industry in Xi'an, Journal of Xi'an Institute of Finance and Economics, Vol.31, No.1, 2018.2. (In Chinese)

[5] W. Xiaobo, Y. Mingming, W. Zhaohui, W. Dong, Classification of business models from the perspective of value network: a case study of modern service industry, Journal of Zhejiang University, humanities and social sciences edition, 2014.3. (In Chinese)

[6] W.Falkenberg \&J.Falkenberg, "Ethics in International Value Chain Networks:The Case of Telenor in Bangladesh,” Journal of Business Ethics,Vol.90,No.3Supplement, 2009, pp.355-369.

[7] Y. Shanlin, Z. Kaile, Z. Qiang, F. Wenjuan, D. Shuai, Yu Bengong, F. Nanping, L. YeZheng, The concept of Internet resources. Journal of management science. Vol.19, 2016, pp.1-11. (In Chinese)

[8] iResearch Consultation, Research Report on O2O service model of Chinese enterprises in 2015[R], 2015. (In Chinese)

[9] Research and development trend forecast report of China's local life service industry in 2016-2022 years[R], China industry survey network. Vol.4, 2016, pp.95-96. No.1913207.(In Chinese) 